\title{
Internalisasi Nilai-Nilai Ukhuwah Kepada Jamaah Melalui Program Layatan pada Organisasi Kemasyarakatan BALADA
}

\section{Muh. Asroruddin al Jumhuri}

Sekolah Tinggi Agama Islam Al-Amin Gersik, Kediri, Lombok Barat asror.fakod@gmail.com

\begin{abstract}
ABSTRAK
Peristiwa kematian adalah sesuatu yang tidak dapat diduga datangnya, akan tetapi terjadi secara mendadak tanpa memberikan kesempatan pada setiap orang yang ditinggal untuk mempersiapkan diri terkait kematian tersebut, sehingga dengan kondisi demikian, sering kali kita melihat kesedihan ketika hal tersebut terjadi bahkan masyarakat di berbagai tempat ikut serta dalam menghadiri upacara pemakaman dan tradisi-tradisi lainnya yang dilakukan setelahnya. Peristiwa kematian dan serangakaian tradisi yang ada di dalamnya menjadikan pengikat tersendiri di antara masyarakat. Hal ini terjadi tidak lain karena keyakinan akan keagamaan yang mereka jadikan sebuah gambaran diri dari masyarakat itu sendiri.

Organisasi Kemasyarakatan BALADA hadir untuk menjawab desakan jamaah yaitu sebagai wadah untuk berkumpul untuk kemudian bersepakat untuk mengadakan programprogram yang bersifat sosial kemasyarakatan. Di antara program yang disepakati adalah program layatan, pengajian dan zikiran.

Internalisasi nilai-nilai ukhuwah kepada jamaah melalui program layatan pada organisasi kemasyarakatan Banjar Layatan Da'watul Khaer (BALADA) dilakukan pada setiap tahapantahapan prosesi layatan: Penyampaian informasi kepaten, Persiapan pengumpulan dan keberangkatan jama'ah ke lokasi kepaten, Prosesi pemakaman dan Prosesi pasca pemakaman

Pada setiap tahapan tersebut pengelola organisasi kemasyarakatan BALADA menanamkan nilai-nilai moral keagamaan terkait tentang ukhuwah, yaitu dengan berusaha melibatkan setiap anggota pada setiap tahapan jika terjadi kepaten.
\end{abstract}

Kata Kunci : Internalisasi, Nilai-nilai Ukhuwah, Layatan, $B A L A D A$

\section{A. Pendahuluan}

Salah satu unsur penting dari kajian tentang struktur sosial adalah dengan keberadaan Organisasi Kemasyarakatan, di antara fungsi adanya Organisasi tersebut adalah sebagai wadah berkumpul sekaligus sebagai penyampai aspirasi untuk kemudian disampaikan kepada pemangku keputusan terhadap kebutuhan dan atau permasalahan yang dihadapi oleh masyarakat.

Social institutions atau disebut juga Organisasi sosial atau Organisasi kemasyarakatan sebagai himpunan norma-norma segala tingkatan yang berkisar pada suatu kebutuhan pokok di dalam kehidupan masyarakat. Social institutions sendiri adalah suatu sistem norma khusus yang menata serangkaian tindakan berpola mantap guna memenuhi suatu keperluan yang khusus dalam kehidupan masyarakat (Koentjaraningrat: 1996). Penyebutan institution dalam sehari-hari sering disamaartikan dengan institut, dalam pengertian Koentjaraningrat di atas institution 
Vol.06-No.02-Desember-2021| Muh. Asroruddin al Jumhuri

Al-Amin: Kajian Pendidikan dan Sosial Kemasyarakatan

diartikannya sebagai pranata, sedangkan institute diartikan sebagai Organisasi; namun dalam sosiologi, pengertian konsep itu tidak demikian walaupun ruang lingkupnya sebenarnya sama.

Terlepas dari definisi di atas, bahwa keberadaan Organisasi kemasyarakatan memang mutlak dibutuhkan di dalam kehidupan bermasyarakat. Peranan dan fungsinya tersebut bersifat langsung, sehingga mutlak dibutuhkan bagi sebagian besar masyarakat dalam kehidupan mereka sehari-hari, termasuk dalam hal ini adalah ketika peristiwa kematian.

Peristiwa kematian sendiri adalah sesuatu yang tidak dapat diduga datangnya, akan tetapi hal tersebut terjadi secara mendadak tanpa memberikan kesempatan pada setiap orang yang ditinggal untuk mempersiapkan diri terkait kematian tersebut, sehingga dengan kondisi demikian, sering kali kita melihat kesedihan ketika hal tersebut terjadi bahkan masyarakat di berbagai tempat ikut serta dalam menghadiri upacara pemakaman dan tradisi-tradisi lainnya yang dilakukan setelahnya. Kegiatan tersebut terus dilakukan dari generasi ke generasi berikutnya karena pada hakikatnya hal tersebut tidak hanya ditujukan bagi kepentingan orang yang telah meninggal saja, melainkan juga bagi orang yang ditinggalkan karena dapat menjadi sarana untuk dapat melewati dan mengatasi kesedihan mereka.

Peristiwa kematian dan serangakaian tradisi yang ada di dalamnya menjadikan pengikat tersendiri di antara masyarakat. Hal ini terjadi tidak lain karena keyakinan akan keagamaan yang mereka jadikan sebuah gambaran diri dari masyarakat itu sendiri. Hal ini juga mengubah pola fikir dan hubungan timbal balik antara individu dan kelompok di dalam masyarakat. Maka media penyatuan di antara mereka dengan masyarakat tercermin dalam kepercayaan yang mereka yakini dan ritual yang mereka lakukan.

\section{B. Internalisasi Nilai-Nilai Ukhuwah}

1. Internalisasi

Menurut Kamus Besar Bahasa Indonesia, istilah internalisasi dimaknai sebagai penghayatan terhadap suatu ajaran, doktrin atau nilai sehingga merupakan keyakinan dan kesadaranakan kebenaran doktrin atau nilai yang diwujudkan dalam sikap dan perilaku. ${ }^{1}$

Dalam kajian psikologis, istilah internalisasi memiliki arti penyatuan sikap atau penggabungan, standart tingkah laku, pendapat, dalam kepribadian. Freud menyakini bahwa super ego atau aspek moral kepribadian berasal dari internalisasi sikap-sikap orang

1 Badan Pengembangan dan Pembinaan Bahasa Kemdikbud RI, 2016, KBBI Version 0.2.1 Beta (21), Jakarta 
Vol.06-No.02-Desember-2021| Muh. Asroruddin al Jumhuri

Al-Amin: Kajian Pendidikan dan Sosial Kemasyarakatan

tua. ${ }^{2}$ Sedangkan menurut Ihsan internalisasi adalah upaya yang dilakukan untuk memasukkan nilai-nilai kedalam jiwa sehingga menjadi miliknya. ${ }^{3}$

Mulyana mengutip pendapat Reber yang mengartikan internalisasi sebagai menyatunya nilai dalam diri seseorang, atau dalam bahasa psikologi merupakan penyesuaian keyakinan, nilai, sikap, praktik dan aturan-aturan baku pada diri seseorang". ${ }^{4}$ Definisi ini mengindikasikan bahwa pemahaman terhadap nilai yang diperoleh haruslah dapat dilakukan dan memberikan dampak pada sikap. Internalisasi ini nantinya akan bersifat tetap dalam diri dan menjadi sebuak keperibadian seseorang.

Dari ketiga pengertian internalisasi di atas jika dikaitkan dengan perkembangan manusia, dapat berarti bahwa proses internalisasi harus sesuai dengan tugas-tugas utama perkembangan seorang manusia. Internalisasi adalah pusat perubahan kepribadian yang merupakan dimensi kritis terhadap perubahan diri manusia baik secara keperibadian maupun watak.

2. Nilai

Kamus Besar Bahasa Indonesia menerjemahkan nilai sebagai sifat-sifat (hal-hal) yang penting atau berguna bagi kemanusiaan; sesuatu yang menyempurnakan manusia sesuai dengan hakikatnya. ${ }^{5}$

Sedangkan menurut Lauis D. Kattsof yang dikutip Syamsul Maarif mengartikan nilai sebagai berikut ${ }^{6}$ : Pertama, nilai merupakan kualitas empiris yang tidak dapat didefinisikan, tetapi kita dapat mengalami dan memahami cara langsung kualitas yang terdapat dalam objek itu. Dengan demikian nilai tidak semata-mata subjektif, melainkan ada tolok ukur yang pasti terletak pada esensi objek itu. Kedua, nilai sebagai objek dari suatu kepentingan, yakni suatu objek yang berada dalam kenyataan maupun pikiran. Ketiga, nilai sebagai hasil dari pemberian nilai, nilai itu diciptakan oleh situasi kehidupan.

Richard T. Schaefer dan Robert P. Lmm (1998) menyatakan nilai adalah suatu gagasan bersama-sama (kolektif) mengenai apa yang dianggap penting, baik, layak dan diinginkan. Sekaligus mengenai yang dianggap tidak penting, tidak baik, tidak layak dan tidak diinginkan dalam hal kebudayaan. Nilai merujuk kepada suatu hal yang dianggap

2 James Caplin, 1993, Kamus Lengkap Psikologi, Jakarta: PT Raja Grafindo Persada,

3 Fuad Ihsan, 2011, Dasar-Dasar Kependidikan, Jakarta: Rieneka Cipta, hal. 155

4 Rahmat Mulyana, 2011, Mengartikulasikan Pendidikan Nilai, Bandung: Alfabeta, hal. 21

5 Badan Pengembangan dan Pembinaan Bahasa Kemdikbud RI, 2016, KBBI Version 0.2.1 Beta (21), Jakarta

6 Ningsih, Misria, 2019, Internalisasi nilai-nilai ukhuwah Islamiyah melalui metode pembiasaan pada siswa di Sekolah Menengah Kejuruan Telkom, Pekanbaru, Riau :UIN SUSKA Riau. 
Vol.06-No.02-Desember-2021| Muh. Asroruddin al Jumhuri

Al-Amin: Kajian Pendidikan dan Sosial Kemasyarakatan

penting pada kehidupan manusia, baik itu sebagai individu ataupun sebagai anggota masyarakat.

Prof Dr. Notonagoro mengemukakan jenis-jenis dalam pengertian nilai sosial yaitu sebagai berikut: ${ }^{8}$

a. Nilai material, yaitu nilai yang mencakup berbagai konsepsi tentang segala sesuatu yang bermanfaat bagi jasmani manusia. Salah satu contoh nilai material yaitu sandang dan pangan.

b. Nilai vital, yaitu nilai yang mencakup berbagai konsepsi yang berhubungan dengan segala sesuatu yang memiliki manfaat bagi manusia dalam melaksanakan berbagai aktivitas. Salah satu contoh nilai vital yaitu buku pelajaran yang berguna bagi siswa saat belajar.

c. Nilai kerohanian ialah nilai yang mencakup berbagai konsepsi yang berhubungan dengan segala sesuatu yang berkaitan dengan kebutuhan rohani manusia. Salah satu contoh nilai kerohanian yaitu beribadah.

Nilai kerohanian dibedakan lagi menjadi 4 macam yaitu:

1) Nilai kebenaran (kenyataan), dapat diartikan sebagai nilai yang sumbernya adalah dari unsur akal manusia (ratio, budi, cipta). Misalnya: garam rasanya asin, gula rasanya manis, matahari adalah bintang, manusia bernapas dengan oksigen, dll.

2) Nilai keindahan, yaitu nilai yang bersumber dari unsur rasa manusia (perasaan, estetis). Misalnya: Tari-tarian, lukisan, patung, perhiasan, dan lain-lain.

3) Nilai moral (kebaikan), yaitu nilai yang bersumber dari unsur kehendak atau kemauan (karsa, etika). Misalnya: norma dalam masyarakat, larangan, aturan, adat istiadat, dan lain-lain.

4) Nilai religious, yaitu nilai ketuhanan, kerohanian yang tertinggi dan mutlak. Misalnya: Ritual-ritual keagamaan.

3. Ukhuwah

Ukhuwah menurut Masyhuri (2018:530) mendefinisikan ukhuwah sebagai persaudaraan karena adanya hubungan pertalian keturunan, kesukuan, agama, profesi, persaan dan sebagainya. ${ }^{9}$ Ukhuwah berasal dari akar kata akhun dengan arti teman akrab atau sahabat. Bentuk jamaknya ada dua yaitu ikhwat yang berarti saudara kandung dan ikhwan yang berarti kawan.

7 https://brainly.co.id/tugas/23370829 (diakses tanggal 21 November 2021)

8 https://www.indonesiastudents.com/pengertian-nilai/ (diakses tanggal 21 November 2021)

9 Masyhuri, Abdul Aziz, 2018, Kamus Super Lengkap (Istilah-Istilah Agama Islam), Yogyakarta: Difa Press. 
Vol.06-No.02-Desember-2021| Muh. Asroruddin al Jumhuri

Al-Amin: Kajian Pendidikan dan Sosial Kemasyarakatan

Kata ukhuwah mengandung makna persamaan, yang akhirnya menimbulkan persaudaraan. Diartikan dengan persaudaraan karena adanya persamaan-persamaan tersebut. Kata saudara (akhun) itu sendiri menurut al-Ragib seorang ahli bahasa al- Qur'an berpendapat pada dasarnya berarti kebersamaan kelahiran dengan orang lain dari dua ibu bapak yang sama, atau salah satu dari keduanya adalah sama atau sepersusuan. Lantas kata itu dipinjam untuk menyebut "kebersamaan" dengan orang lain dalam kesukuan, agama, propesi, pergaulan, kasih sayang dan lain-lain. Secara leterleg penyebutan istilah ukhuwah sering diartikan dengan kata "persaudaraan". Dalam bahasa Arab, kata ukhuwah berasal dari kata $a k h a$, dari kata ini kemudian muncul beberapa turunan kata yaitu al-akh, akhun, yang arti dasarnya adalah "memberi perhatian" dan kemudian berkembang artinya menjadi "sahabat, teman" yang secara leksikal menunjuk pada makna "dia bersama di setiap keadaan", saling bergabung antara selainnya pada suatu komunitas. ${ }^{10}$

Dari beberapa definisi di atas dapat kemudian dipahami bahwa istilah internalisasi nilainilai ukhuwah dapat diartikan sebagai usaha penanaman muatan-muatan atau hal-hal yang berupa kebaikan-kebaikan yang berkaitan dengan ikatan persaudaraan yang dalam hal ini adalah hubungan satu individu dengan individu yang yain yang ada dalam organisasi kemasyarakatan BALADA.

\section{Organisasi Masyarakat BALADA}

BALADA merupakan singkatan dari Banjar Layatan Da'watul Khaer. Lembaga ini adalah sebuah Organisasi kemasyarakatan yang bergerak dibidang sosial kemasyarakatan, khususnya pada program layatan, pengajian dan zikiran. Munculnya lembaga ini atas dasar desakan jama'ah setelah terjadinya perbedaan visi misi dengan Organisasi YATOFA yang merupakan pendahulu dari organisasi BALADA. YATOFA sendiri merupakan singkatan dari Yayasan Attohiriyah Fadiliyah yang berpusat di Bodak, Praya, Lombok Tengah yang juga bergerak di bidang yang sama, yaitu pada bidang sosial kemasyarakatan.

Organisasi Kemasyarakatan BALADA berdiri pada tanggal 8 Dzulhiijah 1441 Hijriyah atau 29 Agustus 2020 Miladiyah yang didirikan atas kesepakatan TGH. Abdul Wasi' Al-Asy’ari, S.Pd.I bersama Tokoh-Tokoh/Penggagas lainnya. Pada saat itu pula disepakati majelismajelisnya dengan menyesuaikan pada peredaran zaman serta berdasarkan "syura" yang dipimpin oleh hikmah kebijaksanaan dalam permusyawatan atau Musyawarah. Organisasi ini

10 Ikhwan Hadiyyin.Konsep Pendidikan Ukhuwah: Analisa Ayat-Ayat Ukhuwah Dalam Al-Qur'an. Vol.33,no.2 (Juli-Desember 2016) hal 28 
berpusat di Kumbak Luah, Desa Setiling, Kec. Batukliang Utara, Lombok Tengah di bawah naungan Pondok Pesantren Da'watul Khaer Kumbak. ${ }^{11}$

Menurut Ahmad Bukran, S.Pd. yang merupakan salah satu pengurus inti mengutarakan bahwa tujuan utama dari terbentuknya BALADA adalah memperkuat ukhuwah dan dakwah melalui program layatan, mengedepankan kepentingan ummat serta menjaga silaturrahim antar jama'ah. ${ }^{12}$ Lebih lanjut ia menyampaikan bahwa hingga saat ini jumlah jama'ah Organisasi Kemasyarakatan BALADA sebanyak 6.430 orang yang berasal dari beberapa kabupaten dan kota di Pulau Lombok.

\section{Pelaksanaan Internalisasi Nilai-Nilai Ukhuwah Kepada Jamaah Melalui Program}

\section{Layatan pada Organisasi Kemasyarakatan BALADA}

Prinsip yang digunakan oleh organisasi kemasyarakatan BALADA dalam menjalankan setiap kegiatannya ialah dengan mengutip ayat al-Qur'an yang terdapat dalam QS. Ali Imran: 104

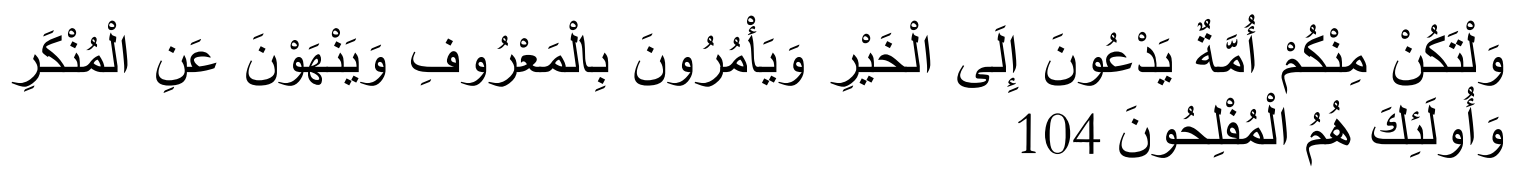

Artinya:

dan hendaklah ada di antara kamu segolongan umat yang menyeru kepada kebajikan, menyuruh kepada yang ma'ruf dan mencegah dari yang munkar; merekalah orangorang yang beruntung.(QS. Ali Imran: 104)

Prinsip ini dijadikan sebagai ruh dalam setiap kegiatan yang dilakukan oleh setiap jamaah anggota BALADA, yaitu amar ma'ruf dan nahi munkar yaitu mengajak kepada kebaikan dan mencegah kemungkaran atau hal-hal yang bersifat ingkar

Pelaksanaan internalisasi nilai-nilai ukhuwah pada organisasi kemasyarakatan BALADA melalui program layatan dilakukan dengan cara yang tidak jauh berdeda dengan prosesi pemakaman pada umumnya. Yaitu dengan menggunakan cara yang sudah ditetapkan oleh syari'at Islam. Dari hasil pemantauan dan wawancara penulis dengan pengurus, pelaksanaan program layatan yang dilakukan oleh jamaah anggota organisasi kemasyarakatan BALADA secara lebih terperinci ialah melalui beberapa tahapan berikut:

1. Penyampaian informasi kepaten

Kepaten merupakan istilah dalam bahasa Sasak Lombok yang jika diartikan ke dalam bahasa Indonesia berarti kematian. Pada tahapan ini informasi terkait kematian salah 
Vol.06-No.02-Desember-2021| Muh. Asroruddin al Jumhuri

Al-Amin: Kajian Pendidikan dan Sosial Kemasyarakatan

seorang jamaah diinformasikan oleh penjaga (marbot) masjid. Selain informasi, marbot juga menganjurkan dan mengajak kepada seluruh jamaah untuk ikut serta dalam prosesi pemakaman.

Pada proses penyampaian informasi tentang kepaten ini, biasanya penjaga atau marbot masjid juga menginformasikan bahwa yang meninggal tersebut merupakan anggota atau jamaah organisasi kemasyarakatan BALADA. Informasi tentang hal ini tentu tidak disampaikan jika yang bersangkutan, yang dalam hal ini adalah orang yang meninggal bukan termasuk anggota organisasi kemasyarakatan BALADA.

Pada tahapan ini, nilai-nilai ukhuwah yang ditanamkan kepada para jamaah seperti yang disampaikan oleh Prof. Dr. Notonagoro terkait nilai kerohanian dalam bersosial ialah berupa penanaman kebiasaan untuk saling mengajak kepada kebaikan seperti yang tercermin dalam QS. Ali Imran: 104.

2. Persiapan pengumpulan dan keberangkatan jama'ah ke lokasi kepaten

Tahapan ini seluruh jamaah yang berkesempatan akan berkumpul di tempat yang sudah ditentukan oleh koordinator dusun untuk kemudian di data. Koordinator dusun kemudian menyediakan moda transportasi untuk mengangkut jamaah ke lokasi kepaten. Pada tahapan ini setiap jamaah diminta untuk mengeluarkan sejumlah dana untuk kemudian diserahkan kepada keluarga yang berduka. Hal ini dilakukan sebagai bentuk solidaritas dan wujud empati kepada keluarga yang ditinggal.

Ada satu aturan tidak tertulis yang kadang di yakini oleh beberapa orang anggota jamaah BALADA yaitu jika mereka ikut berpartisipasi dalam kegiatan layatan, suatu saat nanti jika ia mengalami musibah kepaten, maka orang yang dikunjungi juga pada saatnya akan mengunjunginya juga.

Dalam satu kali layatan jumlah jamaah yang berpartisipasi dari satu wilayah dusun atau desa tidak menentu, yaitu berkisar 15 sampai dengan 25 orang. Akan tetapi setelah sampai di lokasi kepaten, jumlah jamaah yang melayat cukup banyak, karena berasal dari wilayah dan lokasi yang lainnya.

Nilai-nilai ukhuwah yang ditanamkan pada tahapan ini adalah kepedulian terhadap keluarga yang ditinggalkan, yaitu dengan mengharuskan setiap anggota jamaah BALADA untuk mengumpulkan sejumlah dana untuk diberikan kepada keluarga yang ditinggal. Pengurus organisasi dalam hal ini berharap dengan mengumpulkan iuran kepaten ini akan memupuk solidaritas antar sesama muslim, khususnya dengan sesama anggota jamaah.

3. Prosesi pemakaman 
Vol.06-No.02-Desember-2021| Muh. Asroruddin al Jumhuri

Al-Amin: Kajian Pendidikan dan Sosial Kemasyarakatan

Pada saat prosesi pemakaman, jumlah jamaah anggota organisasi masyarakat BALADA semakin bertambah karena berasal dari berbagai wilayah. Selain itu pula banyak pula jamaah yang bukan termasuk dari anggota organisasi yang menghadiri prosesi pemakaman tersebut.

Selain anggota sejumlah tokoh masyarakat, tokoh agama, petinggi organisasi masyarakat BALADA dan Tuan Guru juga ikut serta menghadiri prosesi pemakaman. Tuan Guru sendiri adalah julukan yang disematkan kepada orang yang memiliki pengetahuan agama Islam yang dalam dan luas, yang biasanya juga memiliki lembaga pendidikan. ${ }^{13}$ Gelar ini umumnya diberikan kepada orang yang sudah berhaji, memiliki ilmu dan menyampaikan ilmunya kepada jamaah.

Penanaman nilai-nilai ukhuwah khususnya kepada jamaah organisasi BALADA pada saat prosesi pemakaman ini dilakukan melalui penyampaian ceramah singkat dan uraian singkat oleh Tuan Guru terkait tentang peristiwa kematian dan pentingnya saling menjaga ukhuwah.

4. Prosesi pasca pemakaman

Setelah prosesi pemakaman selesai, pihak keluarga yang berduka mengundang jamaah untuk hadir ke rumah duka untuk berzikir dan mendoakan keluarga yang meninggal dunia. Hal ini dilakukan setiap malam sejak malam kedua hingga malam ke tujuh pasca pemakaman. Kegiatan ini dilakukan selain untuk mendoakan orang yang meninggal dunia, juga ditujukan untuk menghibur keluarga yang ditinggal.

Kegiatan ini umumnya diikuti oleh warga laki-laki dari kampung tersebut. Selain itu acara zikiran dan tahlilan ini juga diikuti juga oleh anak-anak laki, hal ini dimaksudkan untuk menanamkan nilai-nilai bersosial dan bermasyarakat untuk calon-calon generasi tersebut.

Seperti halnya pada tahapan-tahapan sebelumnya, bahwa kegiatan zikir dan tahlilan sejak malam kedua hingga malam ketujuh pasca prosesi pemakaman ini juga secara tidak langsung memberikan pengaruh berupa pendidikan bersosial dan bermasyarakat, termasuk dalam hal ini adalah untuk mempererat ukhuwah dan ikatan persaudaraan antar warga masyarakat.

\section{E. Kesimpulan}

${ }^{13}$ Masyhuri, Abdul Aziz, 2018, Kamus Super Lengkap (Istilah-Istilah Agama Islam), Yogyakarta: Difa Press. Hal.522 
Vol.06-No.02-Desember-2021| Muh. Asroruddin al Jumhuri

Al-Amin: Kajian Pendidikan dan Sosial Kemasyarakatan

Internalisasi nilai-nilai ukhuwah kepada jamaah melalui program layatan pada organisasi kemasyarakatan Banjar Layatan Da'watul Khaer (BALADA) dilakukan pada setiap tahapan-tahapan prosesi layatan sebagai berikut:

1. Penyampaian informasi kepaten

2. Persiapan pengumpulan dan keberangkatan jama'ah ke lokasi kepaten

3. Prosesi pemakaman

4. Prosesi pasca pemakaman

Pada setiap tahapan tersebut pengelola organisasi kemasyarakatan BALADA menanamkan nilai-nilai moral keagamaan terkait tentang ukhuwah, yaitu dengan berusaha melibatkan setiap anggota pada setiap tahapan jika terjadi kepaten.

\section{F. Penutup}

Apa yang penulis sampaikan ini merupakan gambaran kecil dari banyaknya nilai-nilai ukhuwah yang dapat dipetik dalam satu layatan kepaten. Kritik dan saran yang bersifat konstruktif tetap penulis butuhkan untuk menyempurnakan tulisan ini.

\section{G. Daftar Pustaka}

AD/ART BALADA

Badan Pengembangan dan Pembinaan Bahasa Kemdikbud RI, 2016, KBBI Version 0.2.1 Beta (21), Jakarta

https://brainly.co.id/tugas/23370829

https://www.indonesiastudents.com/pengertian-nilai/

Ikhwan Hadiyyin.Konsep Pendidikan Ukhuwah: Analisa Ayat-Ayat Ukhuwah Dalam AlQur'an. Vol.33,no.2 (Juli-Desember 2016)

James Caplin, 1993, Kamus Lengkap Psikologi, Jakarta: PT Raja Grafindo Persada

Fuad Ihsan, 2011, Dasar-Dasar Kependidikan, Jakarta: Rieneka Cipta

Masyhuri, Abdul Aziz, 2018, Kamus Super Lengkap (Istilah-Istilah Agama Islam), Yogyakarta: Difa Press.

Ningsih, Misria, 2019, Internalisasi nilai-nilai ukhuwah Islamiyah melalui metode pembiasaan pada siswa di Sekolah Menengah Kejuruan Telkom, Pekanbaru, Riau :UIN SUSKA Riau.

Rahmat Mulyana, 2011, Mengartikulasikan Pendidikan Nilai, Bandung: Alfabeta

Wawancara dengan Ahmad Bukran, Pengurus BALADA 